\title{
Estimation of IgG and IgM brucella antibodies in infected and non-infected persons by a radioimmune technique
}

\author{
WG HEWITT, DJH PAYNE* \\ From the Public Health Laboratory, St Mary's Hospital, Portsmouth PO3 $6 A Q$
}

SUMMARY Sera from 105 blood donors and eight patients with brucellosis were examined for anti-brucella IgG and IgM by a radioimmune technique. A pooled standard was used for comparison and evaluation. The upper limit of the $99 \%$ confidence interval on the mean of both immunoglobulin classes in blood donor sera was below 7 units $/ \mathrm{ml}$. Antibody response was shown in three acute, two relapsing, two chronic, and one asymptomatic cases. Values of up to 300 units $/ \mathrm{ml}$ of both classes were found in the acute cases. Chronic sufferers showed lower concentra- $\overparen{\Phi}$ tions of antibody. Relapsing cases showed increases comprising mainly IgG. The assay method, $\vec{\varphi}$ which shows general concordance with the results of conventional tests, is useful and measures $\stackrel{\infty}{\oplus}$ individual immunoglobulin classes directly.

Most human cases of brucellosis are diagnosed by recognising the symptoms and by demonstrating the antibodies in the serum. The organism may be isolated from the blood, but bacteraemia is intermittent.' Reliance is therefore placed on immunological procedures, which must be both accurate and informative.

Conventionally, antibodies have been studied using the serum agglutination test, the complement fixation test, and the indirect antihuman globulin assisted agglutination test. From these results the presence and relative proportions of anti-brucella immunoglobulins (IgG and IgM) are inferred and thus the stage of the disease and its activity in the patient are estimated. ${ }^{2-4}$

Previous workers have shown that the titres obtained in conventional serological tests are not absolutely related to the presence and relative proportions of IgG and IgM. Agglutination may be caused by both IgM and IgG, and complement fixation test activity may be high throughout the disease. Acute cases may present with high, low, or undetectable concentrations of antibody. ${ }^{67}$ High titres may be produced in persons, such as veterinarians, exposed to the organism but not clini-

*Dr DJH Payne died in April 1982.

Accepted for publication 5 March 1984 cally suffering from the disease. Mercaptoethanol may be used to differentiate between IgG and IgM activity ${ }^{89}$ but is difficult to control and the results are not readily reproducible between laboratories. The course of the disease may therefore not be reflected fully in the results of conventional tests.

Titres obtained in complement fixation and serum agglutination tests derive from the in vitro activity of the total antibody population of the serum. Procedures have been devised recently which have the advantage of demonstrating the immunoglobulin o classes individually. They include enzyme linked immunosorbent assay ${ }^{10}$ and immunofluorescence $ᄋ$ tests." For some time this laboratory has been $\rightarrow$ examining sera. by means of immunoradiometric assay, and we report here the results obtained with sera from blood donors and from patients with brucella infection.

\section{Material and methods}

SERA

Blood donor sera were obtained from the National $\stackrel{\varrho}{\sim}$ Blood Transfusion Service Laboratory at Southamp- $\square$ ton. Standards for comparison were prepared from pools of specimens showing high serum agglutination and complement fixation test results. Other sera $\mathbb{D}$ were those examined by this brucella reference $\bar{O}$ laboratory. All were stored at $-20^{\circ} \mathrm{C}$ before testing. 
PREPARATION OF ANTIGEN

EEC Standard Brucella abortus antigen (Central Veterinary Laboratory, Weybridge) was centrifuged at $2400 \mathrm{~g}$ for $30 \mathrm{~min}$ and the deposited cells taken up in $0.85 \%(0.124 \mathrm{~mol} / \mathrm{l})$ saline containing $0.4 \%$ $(0.043 \mathrm{~mol} / \mathrm{l})$ phenol. The packed cell concentration was adjusted to $5 \%$ as measured by microhaematocrit.

\section{PREPARATION OF RADIOACTIVE LABELLED ANTIHUMAN GLOBULIN}

Goat antihuman IgM and goat antihuman IgG sera (Technicon) were labelled with ${ }^{125}$ Iodine (Amersham International PLC) by the chloramine $T$ process. ${ }^{12}$ Unbound iodine was removed by gel filtration using Sephadex G25 coarse grade (Pharmacia Fine Chemicals Ltd). After a series of titrations we found that $30 \mathrm{ml}$ of labelled antihuman globulin at a strength suitable for the test could be prepared from the original $2 \mathrm{ml}$ of goat serum. Phosphate buffered saline at $\mathrm{pH} 7 \cdot 3$ (PBS, Oxoid) was used as diluent and eluent.

\section{IMMUNORADIOMETRIC ASSAY}

The method used was similar to that of Parratt et al ${ }^{13}$ and Brown and Lee. ${ }^{14}$ Fifty microlitres of serum or serum diluted in PBS was added to $200 \mu$ l of antigen. After overnight incubation at $37^{\circ} \mathrm{C}$ unbound proteins were removed by repeated washing in PBS containing $2.5 \mathrm{~g} / \mathrm{l}$ of bovine albumin (Fraction $\mathrm{V}$, Sigma) using centrifugation at $2000 \mathrm{~g}$ at $8^{\circ} \mathrm{C}$ for 20 $\mathrm{min}$. The spun deposit was then resuspended in $0 \cdot 2$ $\mathrm{ml}$ of the diluent, $100 \mu \mathrm{l}$ of radiolabelled antihuman globulin (anti-IgG or anti-IgM) was added, and the mixture was incubated at $37^{\circ} \mathrm{C}$ for $90 \mathrm{~min}$. Unbound constituents were removed as previously. The radioactivity present in the washed deposit was measured using a gamma counter (Wilj model 2001).

\section{CALCULATION OF RESULTS}

The amount of IgM and IgG as shown by the test was assigned a numerical value by comparison with a serum standard, to which had been assigned an arbitrary content. This had been adopted after consultation with other workers in the field. Duplicate tests were performed for both immunoglobulin classes in test sera. A standard graph was prepared from examination of dilutions of the standard serum, each being done in triplicate or quadruplicate. Results and statistical analyses were calculated using a microcomputer (CBM).

\section{CONVENTIONAL TESTS}

Serum agglutination, complement fixation, and antihuman globulin assisted agglutination tests were performed according to the methods of Kerr et al. ${ }^{15}$

\section{Results}

Histograms of the distributions of the specific IgM and IgG concentrations of 105 samples of blood donor serum are shown in Figs. 1 and 2. If a Poisson distribution can be assumed, the following statistics are obtained. For IgM: mean $=3 \cdot 11 \mathrm{U} / \mathrm{ml}$, standard deviation $(\mathrm{SD})=1.42 \mathrm{U} / \mathrm{ml}$. For IgG: mean $=2.47$ and $\mathrm{SD}=1.92 \mathrm{U} / \mathrm{ml}$. Ninety nine percent of such blood donors can therefore be expected to have concentrations of less than $7 \mathrm{U} / \mathrm{ml}$ of both immunoglobulin classes.

Forty nine specimens from eight patients suspected of suffering from brucellosis were examined (Table). In many cases the antihuman globulin assisted agglutination test was also performed.

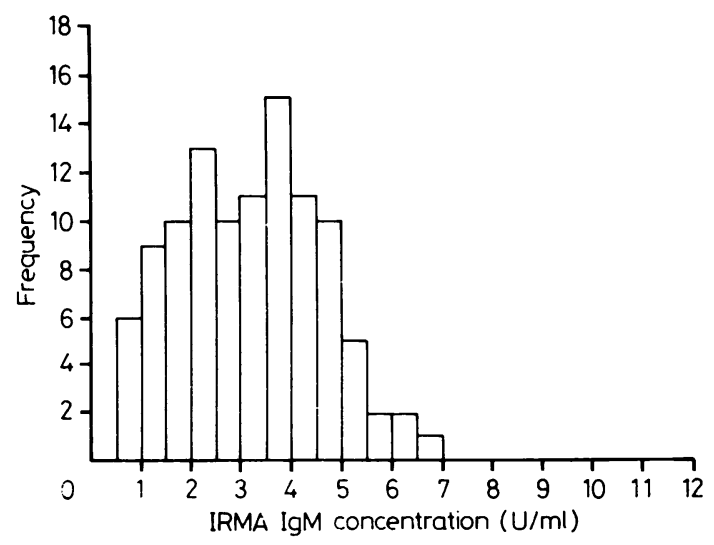

Fig. 1 Distribution of anti-Brucella IgM in 105 blood donors. IRMA = immunoradiometric assay.

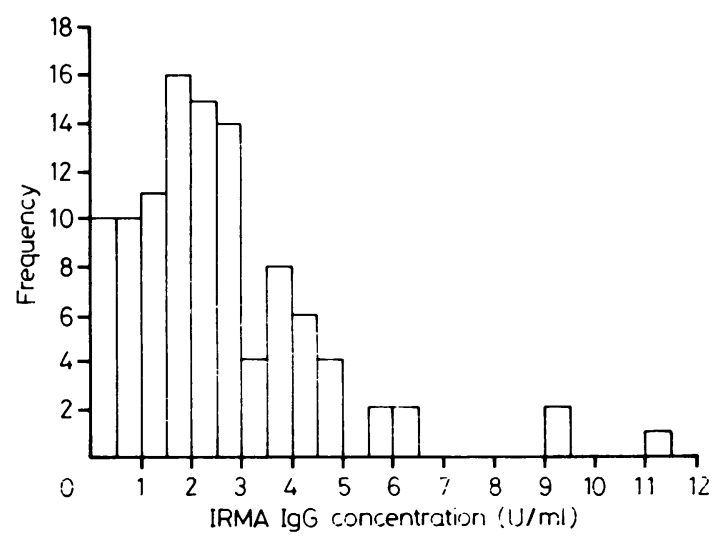

Fig. 2 Distribution of anti-Brucella IgG in 105 blood donors. IRMA = immunoradiometric assay. 
Results of tests on sera from eight cases of brucellosis

\begin{tabular}{|c|c|c|c|c|c|c|c|}
\hline \multirow[t]{2}{*}{ Case no } & \multirow{2}{*}{$\begin{array}{l}\text { Months after onset of } \\
\text { symptoms }\end{array}$} & \multicolumn{2}{|l|}{$S A T$} & \multicolumn{2}{|l|}{$C F T$} & \multicolumn{2}{|c|}{ IRMA } \\
\hline & & $B a b$ & $B$ mel & $B a b$ & $B$ mel & $\lg G$ & IgM \\
\hline 1 & $\begin{array}{l}1 \\
4 \\
5\end{array}$ & $\begin{array}{l}1280 \\
\text { IS } \\
640\end{array}$ & $\begin{array}{c}\mathbf{6 4 0} \\
\text { IS } \\
160\end{array}$ & $\begin{array}{l}\text { IS }_{256} \\
{ }_{256}\end{array}$ & $\mathrm{IS}_{32}^{128}$ & $\begin{array}{l}285 \\
166 \\
142\end{array}$ & $\begin{array}{r}150 \\
17 \\
13\end{array}$ \\
\hline 2 & $\begin{array}{l}1 \\
1 \cdot 3 \\
1 \cdot 8 \\
3\end{array}$ & $\begin{array}{r}5120 \\
2560 \\
2560 \\
640\end{array}$ & $\begin{array}{r}5120 \\
2560 \\
1280 \\
640\end{array}$ & $\begin{array}{r}>256 \\
256 \\
128 \\
32\end{array}$ & $\begin{array}{r}>256 \\
128 \\
32 \\
8\end{array}$ & $\begin{array}{l}37 \\
70 \\
92 \\
52\end{array}$ & $\begin{array}{r}321 \\
280 \\
173 \\
50\end{array}$ \\
\hline 3 & $\begin{array}{l}1 \\
4\end{array}$ & $\begin{array}{l}320 \\
<20\end{array}$ & $\begin{array}{l}640 \\
<20\end{array}$ & $\begin{array}{r}256 \\
64\end{array}$ & $\begin{array}{r}128 \\
64\end{array}$ & $\begin{array}{r}21 \\
107\end{array}$ & $\begin{array}{r}132 \\
42\end{array}$ \\
\hline 4 & $\begin{array}{c}2 \\
3 \\
7 \\
7 \cdot 4 \\
8 \\
10\end{array}$ & $\begin{array}{r}5120 \\
1280 \\
640 \\
640 \\
640 \\
160\end{array}$ & $\begin{array}{r}5120 \\
1280 \\
640 \\
320 \\
320 \\
160\end{array}$ & $\begin{array}{r}>256 \\
>256 \\
>256 \\
64 \\
>256 \\
\mathrm{AC}\end{array}$ & $\begin{array}{l}>256 \\
>256 \\
>256 \\
>256 \\
>256 \\
A C\end{array}$ & $\begin{array}{c}313 \\
223 \\
322 \\
241 \\
\text { IS } \\
78\end{array}$ & $\begin{array}{r}>200 \\
241 \\
73 \\
56 \\
56 \\
\text { IS } 18\end{array}$ \\
\hline 5 & $\begin{array}{l}-8 \\
1 \\
1 \cdot 6 \\
4 \\
13 \\
25 \\
28\end{array}$ & $\begin{array}{r}<20 \\
1280 \\
320 \\
40 \\
<20 \\
<20 \\
640\end{array}$ & $\begin{array}{r}<20 \\
1280 \\
320 \\
<20 \\
<20 \\
<20 \\
160\end{array}$ & $\begin{array}{r}<4 \\
128 \\
>256 \\
8 \\
<4 \\
8 \\
>256\end{array}$ & $\begin{array}{r}<4 \\
128 \\
256 \\
8 \\
<4 \\
4 \\
>256\end{array}$ & $\begin{array}{l}\text { IS } \\
51 \\
94 \\
7 \\
3 \\
4 \\
104\end{array}$ & IS $\begin{array}{r}85 \\
46 \\
4 \\
2 \\
1 \\
7\end{array}$ \\
\hline 6 & $\begin{array}{c}\text { (10 years) } \\
+2 \\
6 \\
11 \\
17 \\
40 \\
47 \\
54 \\
56 \\
60 \\
68\end{array}$ & $\begin{array}{r}80 \\
40 \\
40 \\
<20 \\
80 \\
<20 \\
40 \\
80 \\
80 \\
80 \\
40\end{array}$ & $\begin{array}{r}80 \\
40 \\
40 \\
<20 \\
<20 \\
<20 \\
40 \\
40 \\
80 \\
80 \\
80\end{array}$ & $\begin{array}{r}\text { AC } \\
8 \\
8 \\
16 \\
8 \\
16 \\
\text { AC }^{8} \\
8 \\
8 \\
16 \\
16\end{array}$ & $\begin{array}{r}\text { AC } \\
8 \\
8 \\
16 \\
16 \\
16 \\
\text { AC }^{8} \\
8 \\
8 \\
8 \\
8\end{array}$ & $\begin{array}{c}28 \\
18 \\
18 \\
\text { IS } \\
\text { IS } \\
28 \\
23 \\
19 \\
18 \\
13 \\
11\end{array}$ & $\begin{array}{rr} & 14 \\
& 10 \\
& 10 \\
\text { IS } & \\
\text { IS } & \\
& 13 \\
& 10 \\
& 8 \\
& 5 \\
& 4 \\
4\end{array}$ \\
\hline 7 & $\begin{array}{c}\text { (2 years) } \\
+1 \\
2 \\
4 \\
7 \\
9 \\
10 \\
13 \\
25\end{array}$ & $\begin{array}{r}<20 \\
<20 \\
40 \\
<20 \\
160 \\
160 \\
80 \\
80 \\
80\end{array}$ & $\begin{array}{r}<20 \\
<20 \\
<20 \\
<20 \\
160 \\
160 \\
80 \\
160 \\
40\end{array}$ & $\begin{array}{r}\text { AC } \\
\text { AC } \\
4 \\
128 \\
128 \\
128 \\
32 \\
64 \\
16\end{array}$ & $\begin{array}{l}\text { AC } \\
\text { AC } \\
<4 \\
16 \\
64 \\
64 \\
32 \\
32 \\
8\end{array}$ & $\begin{array}{l}\text { IS } \\
18 \\
17 \\
59 \\
\text { IS } \\
\text { IS } \\
\text { IS } \\
\text { IS } \\
32\end{array}$ & $\begin{array}{lr}\text { IS } & \\
& 10 \\
& 11 \\
& 20 \\
\text { IS } & \\
\text { IS } & \\
\text { IS } & \\
\text { IS } & \\
& 10\end{array}$ \\
\hline 8 & $\begin{array}{l}\text { (No symptoms) } \\
14 \\
27 \\
36 \\
38 \\
40 \\
49\end{array}$ & $\begin{array}{l}<20 \\
<20 \\
<20 \\
320 \\
640 \\
160 \\
<20\end{array}$ & $\begin{array}{r}<20 \\
<20 \\
<20 \\
160 \\
320 \\
80 \\
<20\end{array}$ & $\begin{array}{r}<4 \\
<4 \\
<4 \\
256 \\
256 \\
256 \\
32\end{array}$ & $\begin{array}{r}<4 \\
<4 \\
<4 \\
128 \\
128 \\
64 \\
16\end{array}$ & $\begin{array}{r}\text { IS } \\
5 \\
3 \\
330 \\
159 \\
99 \\
27\end{array}$ & IS $\begin{array}{r}2 \\
2 \\
32 \\
25 \\
14 \\
14 \\
5\end{array}$ \\
\hline
\end{tabular}

$\mathrm{B}$ ab and $\mathrm{B}$ mel $=B$ abortus and $B$ melitensis antigen, respectively, used in the test. Serum agglutination (SAT) and complement fixation (CFT) results are expressed as reciprocals of the titres obtained. Immunoradiometric assay (iRMA) results are expressed as units/ml. IS $=$ insufficient serum for testing. AC $=$ serum anticomplementary.

\section{ACUTE CASES}

Clinical details and the results of conventional serological investigations for cases 1,2 , and 3 were all consistent with the diagnosis of acute brucellosis. Immunoradiometric assay showed that the IgM concentrations were initially high and then fell and that IgG concentrations in cases 2 and 3 continued to rise for a few weeks after the first specimen was taken.
Values attained varied from 3 to 40 times the highest concentration found in the blood donor population.

RELAPSE OR REINFECTION

Case 4 was a retired cricketer working as a schoolmaster in England. He had visited France two months before the onset of symptoms suggestive of 
acute infection. $\mathrm{Br}$ melitensis biotype 1 was grown from blood taken at the same time as specimen 1 (Table). One month later he was symptom free and had completed a course of antibiotics. Four months later the symptoms returned. He had had no known contact with fresh sources of infection. Conventional test results were high, but titres did not rise. Immunoradiometric assay showed a continued fall in IgM, but the IgG had risen above the concentration found in previous tests.

Case 5 was a laboratory worker. A specimen taken before the onset of symptoms showed no antibody activity. Eight months later, after postmortem examination of a brucella infected guineapig, he suffered an "acute attack of brucellosis." All serological investigations showed high concentrations of antibody. Immunoradiometric assay showed that the immunoglobulin concentrations soon fell below $7 \mathrm{U} / \mathrm{ml}$. Two years later he again suffered an "acute attack." Conventional tests showed that antibody concentrations had risen. Immunoradiometric assay showed a slight rise in IgM, which stayed below $8 \mathrm{U} / \mathrm{ml}$, and a much larger rise in IgG, to values higher than those in the first incident. The possibility of reinfection with exogenous organisms cannot be excluded.

\section{CHRONIC CASES}

Cases 6 and 7 were considered on clinical evidence to be suffering from chronic brucellosis. Case 6 had been ill for 10 years before the first specimen was examined. Immunoradiometric assay showed concentrations of both immunoglobulin classes to be slightly above $7 \mathrm{U} / \mathrm{ml}$. Over several years the IgM fell below this value; the IgG also fell, but remained higher than $7 \mathrm{U} / \mathrm{ml}$.

Case 7 was a slaughterman, whose illness had remained undiagnosed for two years before $\mathrm{Br}$ abortus biotype 5 was isolated from his blood. At that time antibodies were not detected by conventional tests, which included the antihuman globulin assisted agglutination test. Immunoradiometric assay, however, showed concentrations above those found in blood donors. Serum agglutination, complement fixation and antihuman globulin assisted agglutination test activity appeared later after "a relapse." IgG and IgM concentrations also rose at this time.

\section{CASE 8}

Case 8 was a laboratory worker in contact with brucellosis. Monitoring over three years failed to detect antibodies until high IgG, IgM, and conventional test results were found. All concentrations fell during the next months. The man never complained of symptoms and so no treatment was given. As far as we know he remains well.

\section{Discussion}

Previous workers have described the patterns of antibody response to brucella infection..$^{235915}$ The results of serum agglutination, complement fixation and antihuman globulin assisted agglutination tests often correspond with the clinical stage of the disease. Where this was so in this study, the immunoradiometric assay results were also as expected. Acute and chronic cases showed high and above normal results both in the conventional tests and in the immunoradiometric assay. In general, all tests can be used to differentiate sufferers from brucellosis from the normal population. Some changes in the relative proportions of the immunoglobulin classes present, however, are shown only by immunoradiometric assay. The rise in specific IgG concentration during the acute phase was shown to be slower than the IgM rise by the results of cases 2, 3 , and 5, in which IgG values were higher in the second or third specimens than in the first, while IgM values fell. Conventional test results on the same sera were high but hid these changes. No specimens were taken during the period when the IgM was rising. This was because the disease is insidious in onset and difficult to diagnose clinically, and so few appropriate samples in the early phase of the disease were submitted. Results from cases 1,2 , 3,6 , and 8 also show that $\operatorname{IgG}$ is slower to fall than IgM in the postacute phase, but that timing is variable. In the chronic phase specific IgM may be below $7 \mathrm{U} / \mathrm{ml}$ but both classes can be above this figure and neither is as high as the concentrations found in the acute phase of the disease.

In case 7 , the immunoradiometric assay showed specific immunoglobulin concentrations higher than those found in normal blood donors at a time when no conventional test activity was demonstrable, even though the patient had symptoms and the organism was cultured from his blood. A similar case in which only the immunoradiometric assay test gave positive results has been examined by this and another laboratory. ${ }^{13}$ This test may therefore be of use in diagnosing infections in which no conventional test activity can be shown.

Immunoradiometric assay also showed immunoglobulin changes during relapse or reinfection. Cases 4 and 5 suffered recurrence of symptoms after a spell of good health. In the first case the already high conventional test results failed to show a further rise in antibody concentrations, and in the second case they gave no indication of the antibody class concerned. Only the immunoradiometric assay showed a large increase in the brucella specific IgG 
content of the serum, with IgM concentrations being less affected. IgG is the major constituent of the secondary humoral immunological response of an immune animal when rechallenged with antigen, as has been shown with brucella infections in cows. ${ }^{16}$ In our experience, however, in many cases of suspected relapse of brucellosis rises in antibody concentrations are not shown by any serological technique. The symptoms may be due to other causes, but until these are eliminated the absence of increases in levels of antibody to brucella cannot be taken to exclude the diagnosis of a relapse.

Comparison of the immunoradiometric assay results and conventional test results shows that although IgG concentrations are broadly related to complement fixation test titres and IgM values broadly related to serum agglutination test titres, individual sera show every combination of high and low serum agglutination and complement fixation test results and IgG and IgM concentrations. This confirms the findings of Parratt et al. ${ }^{13}$ Compared with IgM concentrations serum agglutination test titres showed a correlation coefficient $(r)$ of $\mathbf{0 . 8 8 7 9}$ and gave a Student's $t$ test statistic $(t)$ of 11.42 at 35 degress of freedom (df). The linear correlation is thus significantly different from zero $(p<0.01)$. Similar figures can be derived by comparing complement fixation test titres with IgG concentrations: $\mathrm{r}=0.7210, \mathrm{t}=5.89, \mathrm{df}=32, \mathrm{p}<0.01$. Such statistics ignore the contribution of both classes of immunoglobulin to each conventional test. In cases 2 and 3 complement fixation test titres were falling while IgG concentrations were shown by immunoradiometric assay to be rising; the coincident fall in IgM concentrations may indicate some involvement of the macroglobulin in complement fixation. The high serum agglutination and complement fixation test titres seen in the last specimen from case 5, coincident with high specific IgG concentrations, suggest that this class may cause both agglutination and complement fixation.

Brucella infection is being eradicated from its animal reservoir; consequently, fewer cases are being encountered by doctors. There is still a need, however, for informative laboratory investigations. Brucellosis is endemic in many parts of the world and may be transported across national boundaries. The organism is notorious for causing relapses and producing a chronic disease which may exist undiagnosed for a long time and give rise to a confusing variety of symptoms and signs. It will therefore continue to be considered in the diagnosis of many dis- orders. Clinical examination is necessary to assess $\stackrel{0}{\rightleftarrows}$ the patient, since no laboratory test allows un- 을 equivocal statements. In obscure diagnostic situations the immunoradiometric assay can increase the $\stackrel{\mathcal{D}}{\stackrel{P}{+}}$ amount of useful information available to the doc- $\bar{C}$ tor. It allows direct measurement of brucella specific $\frac{\overline{ }}{\bar{N}}$ immunoglobulin; it is applicable to large numbers of $\frac{\bar{\omega}}{\overrightarrow{0}}$ sera; and it shows features of the immunological $\stackrel{\varnothing}{\varnothing}$ response which may not be detected by conventional serological procedures.

\section{References}

' Spink WW. The nature of brucellosis. Minneapolis: The University of Minnesota Press, 1976.

${ }^{2}$ Wilkinson PC. Immunoglobulin patterns of antibodies against Brucella in man and animals. $J$ Immunol 1966;96:457-63.

${ }^{3}$ Kerr WR, Coghlan Joyce D, Payne DJH, Robertson L. The laboratory diagnosis of chronic brucellosis. Lancet 1966;ii: 1181-3.

${ }^{4}$ Kerr WR, Payne DJH, Robertson L, Coombs RRA. Immuno- globulin class of Brucella antibodies in human sera. Immunology 1967;13:223-5.

${ }^{5}$ Coghlan Joyce D, Weir DM. Antibodies in human brucellosis. $B r(\mathbb{D}$ Med J 1967; ii:269-71.

${ }^{6}$ Payne DJH. Chronic brucellosis. Br Med J 1974,ii:221-2.

${ }^{7}$ Carpenter JL, Tramont EC, Branche W. Failure of routine methods in the diagnosis of chronic brucellosis. South Med J 1979;72:90-1.

${ }^{8}$ Anderson RK, Jenness R, Brumfield HP, Gough P. Brucellaagglutinating antibodies: relation of mercaptoethanol stability to complement fixation. Science 1964;143:1334-5.

${ }^{9}$ Reddin JL, Anderson RK, Jenness R, Spink WW. Significance of $7 \mathrm{~S}$ and macroglobulin Brucella agglutinins in human brucellosis. N Engl J Med 1965;272:1263-8.

${ }^{10}$ Magee JT. An enzyme-labelled immunosorbent assay for Brucella abortus antibodies. J Med Microbiol 1980;13:16772.

" Edwards JMB, Tannahill AJ, Bradstreet CMP. Comparison of indirect fluorescent antibody test with agglutination, comple- $\widehat{\cap}$ ment fixation and Coombs test for Brucella antibody. J Clin Pathol 1970; 23:161-5.

12 McConahey PJ, Dixon FT. Radioiodination of proteins by use of the chloramine T method. Methods Enzymol 1980;70:210-3.

${ }^{13}$ Parratt D, Nielson KH, White RG, Payne DJH. Radioimmunoassay of IgM, IgG and IgA Brucella antibodies. Lancet $\mathrm{O}$ 1977;i:1075-8.

14 Brown WR, Lee E. Radioimmunological measurement of bacter- $I$ ial antibodies. Gastroenterology 1974;66:1145-53.

${ }^{15}$ Kerr WR, McAughey WJ, Coghlan Joyce D, et al. Techniques and interpretations in the serological diagnosis of brucellosis in $\sigma$ man. J Gen Microbiol 1968;1:181-93.

${ }^{16}$ Corbel MJ. The immune response to Brucella abortus 45/20 응 adjuvant vaccine in terms of immunoglobulin class. Dev Biol Stand 1976;31:141-4.

Requests for reprints to: Mr WG Hewitt, Public Health $\stackrel{\mathscr{\Phi}}{\rightarrow}$ Laboratory, St Mary's General Hospital, Milton Road, 0 Portsmouth, Hants PO3 6AQ, England. 